A Journal of Culture, English Language, Teaching \& Literature ISSN 1414-3320 (Print), ISSN 2502-4914 (Online)

Vol. 20 No.2; December 2020

Copyright () Soegijapranata Catholic University, Indonesia

Translator Style: An Analysis on Two Indonesian Translations of "A Scandal in Bohemia"

Suwarni Wijaya Halim

English Language and Culture Department, Faculty of Social Science and Humanities, Bunda Mulia University, Jakarta, Indonesia

email:suwarni@bundamulia.ac.id

Received: 02-04-2020

Accepted: 20-08-2020

Published: 01-12-2020 


\title{
Translator Style: An Analysis on Two Indonesian Translations of "A Scandal in Bohemia"
}

\author{
Suwarni Wijaya Halim \\ suwarni@bundamulia.ac.id \\ English Language and Culture Department, Faculty of \\ Social Science and Humanities, Bunda Mulia University, \\ Jakarta, Indonesia
}

\begin{abstract}
For many years, it is believed that a good translator should be invisible in conducting his or her work. The more transparent and invisible the translator is, the better the quality of translation becomes. However, many experts argued that it is actually impossible for the translators to translate without leaving their thumbprints behind. Thus, the notion of translator style appeared. Studying and exploring the topic of translator style would provide more corroborative support on the view that translators are not merely a mirror of the original author; in fact, they are creative individuals with distinct linguistic characteristics and behaviors, and that translation is not inferior to writing. The objective of this study is to analyze the style of two Indonesian translators of Sir Arthur Conan Doyle's "A Scandal in Bohemia." Moreover, this research also aims to enrich the literature of translator style in the Indonesian context since there are only a few studies about this particular topic in the Indonesian context. This research is qualitative in nature and utilized both corpus-assisted methodology and manual text analysis to gain the data. The findings show that the two Indonesian translators had fundamental differences in their translation. Translator A's style in translating is more oriented to target text and target readers whereas Translators $\mathrm{B}$ are more inclined to adhere to the style of the original author and the source text.
\end{abstract}

Key words: translator style, literary work, short story 
196 Celt: A Journal of Culture, English Language Teaching \& Literature, Volume 20, Number 2, December 2020, pp. 195 - 216

\begin{abstract}
Abstrak: Selama bertahun-tahun, banyak pihak yang meyakini bahwa seorang penerjemah yang baik seharusnya transparan dalam melakukan pekerjaannya. Semakin transparan penerjemahnya, semakin baik kualitas terjemahannya. Namun, banyak ahli berpendapat bahwa sebenarnya tidak mungkin penerjemah menerjemahkan tanpa meninggalkan jejak. Oleh karena itu, gagasan mengenai gaya penerjemah muncul. Mempelajari dan mengeksplorasi topik mengenai gaya penerjemah akan memberikan dukungan yang lebih kuat pada pandangan bahwa penerjemah bukan sekadar cermin dari penulis asli; pada kenyataannya, mereka adalah individu yang kreatif dengan karakteristik dan perilaku linguistik yang berbeda, dan kegiatan penerjemahan itu tidak kalah penting dengan kegiatan menulis. Tujuan dari penelitian ini adalah untuk menganalisis gaya dua penerjemah karya Sir Arthur Conan Doyle yang berjudul "A Scandal in Bohemia" dalam Bahasa Indonesia. Selain itu, penelitian ini juga bertujuan untuk memperkaya literature mengenai gaya penerjemah dalam konteks Indonesia karena hanya ada beberapa studi tentang topik ini dalam konteks Indonesia. Penelitian ini bersifat kualitatif dan menggunakan metodologi berbasis korpus dan analisis teks secara manual untuk mendapatkan data. Temuan penelitian menunjukkan bahwa kedua penerjemah memiliki perbedaan mendasar dalam terjemahan mereka. Gaya Penerjemah A dalam menerjemahkan lebih berorientasi pada teks target dan target pembaca sedangkan Penerjemah $B$ lebih cenderung untuk mematuhi gaya penulis asli dan teks sumber.
\end{abstract}

Kata kunci: gaya penerjemah, karya sastra, cerita pendek

\title{
INTRODUCTION
}

Translator style is an area of translation studies that is under-researched in the past but has gained more and more attention. In her seminal paper in 2000, Baker stated that one of the reasons why there has been little interest in researching the style of individual translators was because of the belief that "a translator cannot have, indeed should not have, a style of his or her own [...]" (Baker, 2000, p. 244). What could have caused such a belief to emerge?

The first cause is the assumption that translation is marginal to the actual writing. It is because many people believed that the process of translation is less creative and less engaging compared to the process of writing. Translators do not have to create the text themselves in the first place; in fact, they only need to convey the message of the text into other 
Halim, S.W., Translator Style: An Analysis on Two Indonesian Translations of 197 "A Scandal in Bohemia"

languages by using the text created by the writer as a template. Since the effort and burden to creatively compose the text falls on the writer, many people deemed that translators have an easier task, which then borne the belief that translation is secondary to the writing.

The second cause is the expectation that translators should act as an invisible bridge in doing their job, giving the impression that they did not exist. It was as if the author of the source text was fluent in the target language, and the target readers were reading the text which was directly composed by the original author. Thus, the notion of translator style should not have existed in the first place since it is expected that the translators convey the author's style and message faithfully to the target readers without any interference from other external factors.

As a result, the notion of translation invisibility became significantly popular in the past. Venuti mentioned that in the past, "a translated text [...] is judged acceptable by most publishers, reviewers and readers when it reads fluently, when the absence of any linguistic or stylistic peculiarities makes it seem transparent ..." (2008, p. 1). For many years, the subtlety and the ability to remain invisible in the translation has been one of the most sought-after quality in the process of translating. The more transparent and invisible the translator is, the better the quality of translation becomes.

However, as time passed and as the study on the nature of translation progressed further, more and more researchers believed that it is actually impossible for the translators to translate without leaving their thumbprints behind. Baker argued that "... it is impossible to produce a stretch of language in a totally impersonal way as it is to handle an object without leaving one's fingerprints on it" (2000, p. 244).

She further demonstrated her arguments by attempting to establish the methodology for analyzing the translator style. Baker (2000) used the Translational English Corpus (TEC) to analyze the style of Peter Bush and Peter Clark, two distinguished British literary translators in translating source texts from different languages. The result shows that Peter Bush and Peter Clark used distinctive patterns, particularly in type/token ratio, the average length of the sentences, and reporting structures.

Hence, more and more researchers are interested to try to conduct investigations for a similar purpose: to prove that translators are not merely a mirror of the original authors. Some researchers employed manual 
contrastive and text analysis to pinpoint the translator style in many results of translation. For instance, Marco (2004) analyzed the style of two Catalan translators, namely Josep Carner and Carles Riba in translating the works of Henry James and Edgar Allan Poe by paying considerable attention to the aspect of structural calque applied by both translators. He also analyzed the transitivity pattern of the original authors and compared it with the transitivity pattern produced in the translations by the two translators. Another researcher, Masubelele (2015) analyzed the translation of D.B Z. Ntuli's short story, which was written in isiZulu, into English by C.S.Z. Ntuli. The researcher compared and contrasted the source text and the target text and found that the translator actually included much more information into the translation as a way of compensating differences in cultures. This is especially apparent in terms of the translation of cultural-specific items, sentence structures, and the use of descriptive terms.

Then the scope of the research was broadened due to the advancement of technology. Many researchers followed Baker's footsteps by utilizing data from corpora. Wang and $\mathrm{Li}$ (2011) used a corpus-based approach to conclude the translator style belonging to two Chinese translators, namely Xiao and Jin, who translated James Joyce's "Ulysses". The result shows that both translations are indeed different in lexical and syntactical level. Mastropierro (2018) suggested the use of key clusters to identify the translator style. He compared two Italian translators' translation of "At the Mountains of Madness" by H. P. Lovecraft. The result shows that key clusters can be a good indicator of identifying the translator style.

The studies above have exemplified varieties of topics, data, and methods in analyzing translation work for the purpose of identifying the translator style. However, there are only a few studies about this particular topic in the Indonesian context. It is probably caused by the fact that most of the previous researchers used literary work by one author and compared and contrasted its different versions of translation by two (or more) translators. However, in Indonesia, it is very rare to find a literary work that has been translated more than once by different translators. Moreover, most of the studies explained above used either manual or automatic means in analyzing the translator style. There are only a few studies in this area that employs both means when in fact, it would actually provide stronger and more convincing arguments.

In order to fill this gap and to enrich the literature of this topic in the Indonesian context, the researcher is interested in analyzing the translation of 
Halim, S.W., Translator Style: An Analysis on Two Indonesian Translations of 199 "A Scandal in Bohemia"

Sir Arthur Conan Doyle's story "A Scandal in Bohemia," which is a part of a larger collection of stories entitled "The Adventures of Sherlock Holmes." As far as the researcher's awareness, the translated version of the book has been published twice by different publishers. The first version was translated by Dra. Daisy Dianasari (hereinafter, Translator A) and published by PT. Gramedia Pustaka Utama in 1992 whereas the second version was translated by Ismanto, et al. (hereinafter, Translators B) and published by Penerbit Indoliterasi in 2014.

This research would attempt to answer the following research question: How are the styles of Translator A and Translators B in translating "A Scandal in Bohemia"? To answer the research question, the researcher would employ both manual and automatic means in studying the translators' style. In other words, the researcher would conduct both manual text analysis and the method of corpus linguistics. By employing both means, hopefully, more comprehensive results could be achieved and more interesting insights about the research topic could be gained.

This research only focuses on one story by Sir Arthur Conan Doyle entitled "A Scandal in Bohemia" and its translations in Indonesian as explained in the previous section. The analysis would be highly textual and descriptive as the research focuses on the area which emphasizes and highlights differences between two groups of translators.

\section{LITERATURE REVIEW}

\section{A. Translator Style}

The notion of translator style is different from the notion of translation style (Saldanha, 2011). Translation style concerns about the style in which the source text is written and how that particular style is reflected in the translation. On the other hand, the translator style focuses more on the translators' idiosyncrasy and characteristics which are unique, specific and consistent throughout the whole translation.

Baker defined translator style as "a kind of thumb-print that is expressed in a range of linguistic-as well as non-linguistic-features" in the translation works produced by translators (2000, p. 245). Meanwhile, Saldanha defined translator style as: 
A way of translating which is felt to be recognizable across a range of translations by the same translator, distinguishes the translator's work from that of others, constitutes a coherent pattern of choice, is 'motivated', in the sense that it has a discernable function or functions, and cannot be explained purely with reference to the author or source-text style, or as the result of linguistic constraints (2011, p. 31).

Baker (2000) explained that the study on translator style should not be limited to the study on the usage of specific strategies in dealing with translation problems, but also extend to the specific ways the translators use the language. Baker also emphasized the analysis of language patterns, which involves "describing preferred or recurring patterns of linguistic behavior [...]" (2000, p. 245).

Similarly, Lynch \& Vogel (2018) suggested scrutinizing patterns of grammatical elements in the text instead of focusing on the content words, such as nouns or verbs. They believed that the patterns of "stylistics elements such as pronouns, prepositions, conjunctions, and other closed-class words" provide information and indication on the style of the translators (Lynch \& Vogel, 2018) since translators often, consciously or unconsciously, use these elements in their own ways when they are translating texts. Aspects, such as the usage of tenses, could also indicate the style of translators. Wang and $\mathrm{Li}$ added that the translator style can also be seen and concluded from "the selection and organization of words, the long or short sentence structures, the plain or oratory way of speech" (2011, p. 82).

From the definitions above, it can be concluded that the notion of translation style focuses on the idea that individual translators have their own characteristics and idiosyncrasies when they are translating. They might or might not be aware that they display distinct linguistic behavior. In order to identify whether the way of translating indeed belongs to the translators or it is just a mere reflection of the content of the source text, it is necessary to pay considerable attention to the patterns of linguistic behaviors of the translators and compare and contrast them to the patterns of linguistic behaviors that belong to other translators.

\section{B. Previous Studies}

Li, Zhang, \& Liu (2011) conducted a study to examine the styles of two groups of translators, namely Hawkes and Minford, and Yang and Yang. 
Halim, S.W., Translator Style: An Analysis on Two Indonesian Translations of 201 "A Scandal in Bohemia"

Both groups of translators translated the Chinese novel entitled Hongloumeng from Chinese into English, and the researchers sought to conclude the styles of both groups of translators, compare them, and try to examine the reasons why both groups of translators translated the text the way they did. To analyze the data, the researchers built a parallel corpus, which includes the original text in Chinese, the English translation by Hawkes and Minford, and the English translation by Yang and Yang.

They then used Wordsmith 4.0 and a type of software that integrates ASP (Active Server Page) and Microsoft Access Database to analyze the data. The researchers followed Baker's methodology (2000) by only comparing across the target texts instead of comparing the source text and the target texts, and they focused on the type/token ratio, richness of vocabulary, and average length of the sentences. The result of their analysis shows that Hawkes used more words and longer sentences, yet Yang had more word varieties in the translation. $\mathrm{Li}$, Zhang, and Liu speculated that both translators might have had different ideologies in translating and might have used different strategies in dealing with cultural-specific concepts.

Similarly, Wang \& Li (2011) also used the corpus-assisted methodology to analyze the translators' style by looking at the Chinese translation of Ulysses by James Joyce. Wang and Li created a two-million-word bilingual corpus of which consists of three subcorpora-composed of the original English version, the translation by Xiao, and the translation by Jin-and a comparable corpus containing other translation and writing work by Xiao. The result of the analysis shows that Xiao and Jin have their own idiosyncrasies which are subtle but habitual. On the lexical level, for example, one of the stylistic differences is the fact that Xiao apparently prefers to reflect colloquial nature by using more words that express emotion whereas Jin prefers more detached manner in his/her way of translating. However, on the syntactical level, Xiao and Jin actually exhibited similar behavior in term of translating postpositioned adverbial clauses. Both were apparently influenced by the source text and translated the clauses in the post position as well despite the fact such positioning is less common in Chinese.

Masubelele (2015) did not use the corpus-assisted methodology in her study. Instead, she employed manual discourse analysis in order to analyze the translation of D.B Z. Ntuli's short story, which was written in isiZulu, into English by C.S.Z. Ntuli. The main theory that Masubelele used is Baker's theory of equivalence at word level. In this research, the researcher compared and contrasted the source text and the target text and found that the 
translator actually included much more information into the translation as a way of compensating differences in cultures. This is especially apparent in terms of the translation of cultural-specific items, sentence structures, and the use of descriptive terms.

Similar to Masubelele, Giugliano (2017) also conducted manual analysis in his pursuit in describing the style of translator, specifically contrastive linguistic analysis. The source of data that he used in his study was a collection of poems by Robert Frost and the Italian translation by Giovani Giudici. He started his analysis by describing Robert Frost's style and Giudici's style before analyzing the translations.

Some stylistic points (such as markers of turn-taking, syntactical complexity, deixies, metre in translation and so on) were analyzed, and the frequency of the occurrences were calculated. In the end, Giugliano concluded that the translator's creativity is indeed apparent in the translation. Some linguistic features in the source text were, in fact, reduced in the translation, yet some other features were enhanced instead, proving that the translator actually interfered a great deal in the process of translation instead of translating the source text as it was.

The research by Masubelele (2015) and Giugliano (2017) is fundamentally different from the research by Li, Zhang, \& Liu (2011) and Wang \& Li (2011). It is because Li, Zhang, \& Liu (2011) and Wang and Li (2011) only focused on the comparison across the translation works without comparing the works to the source text in their process of identifying the translator style. Masubelele (2015) and Giugliano (2017), on the other hand, compared the translation work with the original work in order to discover the style of the literary translator.

Each of the research above is useful and informative for this research. The aim of this research is similar to previous studies. However, the researcher will use different datasets in different language pair. Typically, the studies that have been conducted previously only employed either manual or automatic means in the process of identifying the translator style. In this research, the researcher would attempt to combine both means in order to get more comprehensive and valid information on the translator style. 
Halim, S.W., Translator Style: An Analysis on Two Indonesian Translations of 203 "A Scandal in Bohemia"

\section{METHOD}

The sources of data are two translation works. The translation work that the researcher would analyze further was originally written in English by Sir Arthur Conan Doyle, and it is a part of a larger compilation of short stories entitled "The Adventures of Sherlock Holmes." The story that the researcher would like to focus on is entitled "A Scandal in Bohemia" in English and its translations in Indonesian, "Skandal di Bohemia." The story tells about one of the cases that Mr. Sherlock Holmes and Mr. John Watson went through and solved, and in this story, a female character namely Irene Adler was introduced.

\section{Table 1:}

\section{Information on Source of Data}

\begin{tabular}{lll}
\hline & \multicolumn{1}{c}{$1^{\text {st }}$ Version } & \multicolumn{1}{c}{$2^{\text {nd }}$ Version } \\
\hline Title & "Skandal di Bohemia" & "Skandal di Bohemia" \\
\hline Publisher & PT. Gramedia Pustaka Utama & Penerbit Indoliterasi \\
\hline $\begin{array}{l}\text { Year of } \\
\text { Publication }\end{array}$ & 1992 & 2014 \\
\hline Translators & $\begin{array}{l}\text { Translator A (Dra. Daisy } \\
\text { Dianasari) }\end{array}$ & Translators B (Ismanto, et al.) \\
\hline
\end{tabular}

There are several limitations regarding the source of data (see Table 1). First, the translations were published by two different publishers. Each publisher might have had different agenda and might have provided distinctive translation brief and instructions. However, the researcher unfortunately could not obtain the relevant information to confirm the notion. Second, there are more than twenty years of time span between the first and second version, so the language used during those times might be different. Finally, the researcher could not manage to find information about the translators' background, so the analysis on translators' motivation and reasoning might be very limited in nature.

Despite the limitations, the researcher thought that using both of these translations as the source of data is an appropriate decision considering the dearth of foreign literary works in Indonesia that have been translated more than once by different translators into Indonesian. The researcher believed that these translations could provide opportunities for the researcher to delve deeper into the field of translator style and reach the conclusion about the 
style of Indonesian translators of "A Scandal in Bohemia." As a result, the researcher decided to use both the translations as the source of data.

\section{A. Type of Research}

This research is qualitative in nature. Crocker explained that "qualitative research mostly focuses on understanding the particular and the distinctive, and does not necessarily seek or claim to generalize findings to other contexts" (2009, p. 9). He also specified that the primary data of qualitative research is usually textual, and numbers do not play a central role in qualitative research; instead, they only act as support for the textual data (Crocker, 2009).

This research, meanwhile, focuses on two translation works and attempts to find out and comprehend the individual translator style which is unique for each translator. Thus, the result of the research might not be generalizable to other translators. Moreover, numbers or any quantitative aspects would not be the major focus of this research. They would only provide additional information. Therefore, looking at the definition and characteristics of qualitative research, the researcher believed that the qualitative approach would suit this research best.

\section{B. Research Instruments}

There are two main research instruments in this research. As explained in Table 1, the research would use both manual and automatic means in order to elicit information about translator style in translating. The first instrument is the software Wordsmith Tools 7.0 which was created by Scott (2016). Wordsmith Tools 7.0 is a corpus analysis toolkit that is designed specifically to assist in the process of text analysis. By using this software, the researcher could get much useful information, such as the type/token ratio, concordances, lexical bundles, and so on, which would be beneficial in discovering the translator style (Baker, 2000; Li, Zhang, \& Liu, 2011; Wang \& Li, 2011).

The second instrument is the researcher herself. For the manual aspect, the researcher would act as the primary instrument in this research because the researcher would be manually comparing and contrasting both translation works in order to identify the unique features in both translations. 
Halim, S.W., Translator Style: An Analysis on Two Indonesian Translations of 205 "A Scandal in Bohemia"

\section{Research Procedures}

To collect the data, the researcher inputted the files of both translations into Wordsmith Tools 7.0 in order to acquire further information about the type/token ratio, average sentence length, and keywords. After the information was acquired, the researcher provided elaboration and examples to explain the phenomena.

The researcher then manually compared the translations by both translators. The researcher focused on the elements that might be problematic for the translators and analyzed how the translators dealt with those translation problems. The elements were then grouped under the relevant categories in order to gain insights on each translator's individual style in translating. Afterwards, the researcher explained the implication of the findings on the body of the knowledge.

\section{RESULTS AND DISCUSSIONS}

\section{A. Type/Token Ratio}

Type/token ratio (TTR) is a measure to identify the diversity of vocabulary. By identifying the TTR, the researcher could analyze the extent of vocabulary used by Translator $A$ and Translators B in translating the source text, which in turn could help the researcher analyze the lexical behavior of each translator. TTR is calculated by dividing the number of types (distinct words) with the number of tokens (all words) of the text. The higher the TTR, the more diverse the vocabulary whereas the lower the TTR, the more limited the vocabulary.

In this case, instead of using raw TTR, the researcher would use standardized type/token ratio (STTR) because according to Baker, 2000 and $\mathrm{Li}$, Zhang, and Liu (2011), STTR provides a more reliable overview of the diversity of vocabulary. It is because the calculation of STTR is repeated every 1000 words which will ensure the credibility of the result. Below is the information on TTR and STTR that the researcher acquired after running both translations into WordSmith Tools 7.0: 
Table 2:

TTR and STTR

\begin{tabular}{ccccc}
\hline Translator & $\begin{array}{c}\text { Number of } \\
\text { Types }\end{array}$ & $\begin{array}{c}\text { Number of } \\
\text { Tokens }\end{array}$ & TTR & STTR \\
\hline Translator A & 1,907 & 6,846 & $27.86 \%$ & $49.05 \%$ \\
\hline Translators B & 1,912 & 7,549 & $25.33 \%$ & $47.46 \%$ \\
\hline
\end{tabular}

From Table 2 above, it can be seen that the number of types between both translators is quite similar, but according to the number of the tokens, Translators B used considerably more words than Translator A. The result also shows that Translator A has slightly higher TTR and STTR compared to Translators B, which means that Translator A used more diverse vocabulary compared to Translators B. One of the examples of the usage of diversity in terms of vocabulary can be seen from the way the translators translated reporting verbs in the source text. Reporting verbs are commonly used to signal dialogues in novels. Some examples of reporting verbs are "said", "commented", "remarked", and so on. In the case of the translations, some reporting verbs were translated identically by Translator A and Translators B. For example, both translators translated reporting verb "said" into kata or berkata. However, in other cases such as the reporting verb remarked, Translator A translated it as komentar whereas Translator B translated it as menukas.

\section{B. Average Sentence Length}

Type/token ratio (TTR) is used to acquire information on the behavior and style of the translators from the lexical point of view. The researcher was also interested to investigate their behavior and style from the syntactical point of view. Therefore, the researcher also analyzed the average sentence length in both translations. This information can be acquired by dividing the number of sentences with the number of tokens. Using the same procedure to acquire the value of TTR and STTR, below is the information on the average sentence length:

Table 3:

Average Sentence Length

\begin{tabular}{cccc}
\hline Translator & $\begin{array}{c}\text { Number of } \\
\text { Sentences }\end{array}$ & $\begin{array}{c}\text { Number of } \\
\text { Tokens }\end{array}$ & $\begin{array}{c}\text { Average Sentence } \\
\text { Length }\end{array}$ \\
\hline Translator A & 676 & 6,846 & 10.13 \\
\hline Translators B & 636 & 7,549 & 11.87 \\
\hline
\end{tabular}


Halim, S.W., Translator Style: An Analysis on Two Indonesian Translations of 207 "A Scandal in Bohemia"

From Table 3, it can be seen that Translator A constructed more sentences than Translators B. The value of average sentence length also shows that Translators B tended to use more words in a sentence compared to Translator A.

There are two possible explanations for this finding. This might mean that Translator A either prefers using more concise wordings in a sentence or prefers dividing long and complex sentences into several shorter sentences. The example presented below in Table 4 illustrated these phenomena.

\section{Table 4:}

\section{Example of Average Sentence Length}

\begin{tabular}{cl} 
Source Text & $\begin{array}{l}\text { But for the trained reasoner to admit such intrusions into his own } \\
\text { delicate and finely adjusted temperament was to introduce a } \\
\text { distracting factor which might throw a doubt upon all his mental } \\
\text { results. (Doyle, 1892) }\end{array}$ \\
\hline Translator A & $\begin{array}{l}\text { Tapi bagi dirinya sendiri, hal-hal begitu malah akan mengacaukan seluruh } \\
\text { pemikirannya. (Doyle, 1992) }\end{array}$ \\
Translators B & $\begin{array}{l}\text { Namun, bagi seorang pemikir yang terlatih, memasukkan gangguan } \\
\text { semacam itu ke dalam wataknya yang lembut dan seimbang berarti } \\
\text { memperkenalkan sebuah faktor pengacau yang barangkali dapat } \\
\text { menyebabkan kesangsian atas semua hasil pikirannya. (Doyle, 2014) }\end{array}$
\end{tabular}

In the example above, Translator A used 11 words while Translators B used 31 words in translating the same excerpt. Hence, there is an impression that Translator A chose to use more concise and brief wordings in the process of translation whereas Translators B are more inclined to keep their translation as close as possible to the source text.

\section{Translation of Problematic Parts}

By comparing the translations manually, it is evident that both translators have their own distinctive ways of translating the story. The following excerpt exemplifies one of such phenomena:

\section{Table 5:}

\section{Translation of Problematic Parts (Example 1)}

\begin{tabular}{ll}
\hline Source Text & "I think, Watson, that you have put on seven and a half pounds \\
& since I saw you." \\
& "Seven!" I answered. (Doyle, 1892)
\end{tabular}


208 Celt: A Journal of Culture, English Language Teaching \& Literature, Volume 20, Number 2, December 2020, pp. 195 - 216

\begin{tabular}{ll}
\hline Translator A & "Kurasa, Watson, beratmu naik tiga tiga perempat kilo dibanding terakhir \\
& kali aku melihatmu." \\
& "Cuma tiga setengah kilo naiknya," jawabku. (Doyle, 1992) \\
\hline Translators B & "Watson, kukira kau sudah bertambah berat tujuh setengah pon setelah \\
& terakhir kali aku melihatmu," \\
& "Tujuh," jawabku. (Doyle, 2014) \\
\hline
\end{tabular}

In the example seen in Table 5 above, in translating the measurement for Watson's body weight, Translator A converted and adjusted the measurement and the metric into kilograms whereas Translators B used the same measurement and the metric as the source text, which is the equivalence of "pounds" in Indonesian, pon.

Pound is a common metric to use in England whereas Indonesians are more familiar with kilograms or grams as the metric for weight measurement. That might be the reason why Translator A decided to adjust the translation so that the translation does not sound foreign to the target readers. Meanwhile, Translators B translated "pounds" into pon, which is the equivalence in Indonesian, and this metric is not entirely unknown to Indonesian people. It is, however, used less compared to kilograms or grams.

Another instance can be seen from the way the translators translated the cultural term "sovereign" as illustrated in the following Table 6:

Table 6:

Translation of Problematic Parts (Example 2)

\begin{tabular}{ll}
\hline Source Text & $\begin{array}{l}\text { "The Church of St. Monica, John,' she cried, 'and half a sovereign } \\
\text { if you reach it in twenty minutes.' (Doyle, 1892) }\end{array}$ \\
\hline Translator A & $\begin{array}{l}\text { "'Ke Gereja St. Monica, John!' teriaknya. 'Kubayar satu koin emas kalau } \\
\text { kau bisa menempuhnya dalam dua puluh menit'. (Doyle, 1992) }\end{array}$ \\
\hline Translators B & $\begin{array}{l}\text { "Gereja St. Monica, John," serunya, "dan setengah sovereign kalau kau bisa } \\
\text { sampai di sana dalam waktu dua puluh menit." (Doyle, 2014) }\end{array}$
\end{tabular}

Sovereign is defined as "any of various gold coins of the United Kingdom" ("Sovereign", n.d.). Although the idea of using gold coins as a means of payment is not a foreign concept for Indonesian readers, the word sovereign could still be classified as a cultural term since it is unique for the context of the United Kingdom. Translator A translated the term into a more general translation, which is koin emas whereas Translators B transferred the term "sovereign" from the source text into the target text. 
Halim, S.W., Translator Style: An Analysis on Two Indonesian Translations of 209 "A Scandal in Bohemia"

Translator A might think that the translation koin emas ("gold coin") would provide a more concrete image for the Indonesian readers since most Indonesians would recognize what koin ("coin") looks like and how valuable emas ("gold") is. In comparison, Translators B copied the term directly from the source text into the target text.

Another difference can be seen from the way the translators handled proper names. Below is the example that illustrates such a difference.

Table 7:

Translation of Problematic Parts (Example 3)

\begin{tabular}{ll}
\hline Source Text & “... Stay where you are. I am lost without my Boswell ...” (Doyle, \\
& 1892)
\end{tabular}

In the story, Dr. Watson intended to leave Mr. Holmes so that Mr. Holmes could leisurely receive his mystery guest without any disturbance. However, Mr. Holmes urged Dr. Watson to stay. In Table 7, it can be seen that Translator A rendered the proper name "Boswell" into yang mendampingi whereas Translators B transferred the name as it is in their translation, which is "Boswell." The name "Boswell" might refer to James Boswell, a Scottish biographer of Samuel Johnson, an English writer. According to Encyclopedia Britannica, James Boswell is considered as "one of the world's greatest diarist" (James Boswell, n.d.). In the whole course of the Sherlock Holmes series, Dr. Watson frequently documented Mr. Holmes's actions when solving cases, which earned him the unofficial role as Mr. Holmes's biographer. By stating that Mr. Holmes would be lost without his Boswell, the author intended to point out the similar characteristic between Dr. Watson and James Bowell and highlight that Dr. Watson was Mr. Holmes's partner and biographer.

By translating the name into yang mendampingi, Translator A minimized the possibility of the readers misunderstanding the reference and the content of the utterance although she, in return, did not adhere to the author's style. Meanwhile, Translators B adhered to the source text and transferred the name directly into the target text, yet there is a possibility that the target readers might not understand the reference since James Boswell might be an unfamiliar figure in Indonesian culture. 
210 Celt: A Journal of Culture, English Language Teaching \& Literature, Volume 20, Number 2, December 2020, pp. 195 - 216

The last instance of the translation of problematic parts can be seen from the way the translators translated the term "née" as illustrated in the following Table 8:

\section{Table 8:}

\section{Translation of Problematic Parts (Example 4)}

\begin{tabular}{ll}
\hline Source Text & Irene Norton, née Adler (Doyle, 1892) \\
\hline Translator A & Irene Norton, d/h Adler (Doyle, 1992) \\
\hline Translators B & Irene Norton, née Adler (Doyle, 2014) \\
\hline
\end{tabular}

According to Merriam-Webster Dictionary, the term "née" is used "after a married woman's name to identify the family name that she had when she was born" (Née, n.d.). In the story, the character Irene Adler got married to Edward Norton, and she changed her name into Irene Norton. As seen in the table, Translator A translated the term into $d / h$ whereas Translators B kept the term in their translation.

The term "née" does not exist in the Great Dictionary of the Indonesian Language and might not be a familiar term for Indonesian readers. Therefore, Translator $\mathrm{A}$ in this case might be trying to find the equivalence of such term in Indonesian, possibly, in order to ensure that the target readers understand the meaning that the original author would like to convey. Thus, she chose $d / h$ as the ideal translation. According to Kusno (2015), $d / h$ was the abbreviation of dahulu ("once upon a time in the past"), and it was used back then during the transfer of the sovereignty from the government of the Netherlands to the government of Indonesia. Before the independence of Indonesia, most of the landmarks, roads, and buildings were named in Dutch. After the transfer of sovereignty, however, some names were changed into Indonesian names. To avoid confusion during the transition period, people used $d / h$ in order to provide information on the new and the old names. Kusno (2015) provided Lapangan Banteng $d / h$ Waterlooplein as an example. It means that Lapangan Banteng was once named Waterlooplein. By translating the excerpt into Irene Norton, $d / h$ Adler, the meaning that the translator conveyed is essentially similar to the meaning that the original author would like to convey ("Irene Norton whose maiden name was Adler before she got married") despite the fact that the translator used abbreviation in Indonesian instead of transferring the term into the target text. On the other hand, Translators B decided to do exact opposite of Translator A. Translators B directly transferred the term into their translation 
Halim, S.W., Translator Style: An Analysis on Two Indonesian Translations of 211 "A Scandal in Bohemia"

without providing any further explanations. This phenomenon shows that Translators B might prefer translating the text in a faithful manner. This is evident from the way Translators B directly copied the term.

\section{Degree of Formality}

By conducting the manual comparison, it can be seen that both translators have distinctive ways of translating the conversation between $\mathrm{Mr}$. Holmes and Dr. Watson. This is particularly evident in the expression of formality in the translations. The following excerpts in Table 9 illustrates this phenomenon.

\section{Table 9: \\ Rendition on Degree of Formality}

\begin{tabular}{cl}
\hline Source Text & $\begin{array}{l}\text { "Indeed, I should have thought a little more. Just a trifle more, I } \\
\text { fancy, Watson. And in practice again, I observe. You did not tell me } \\
\text { that you intended to go into harness." } \\
\text { "Then, how do you know?" (Doyle, 1892) }\end{array}$ \\
\hline Translator A & "Wah, seharusnya aku lebih teliti. Cuma selisih sedikit, kan? Dan sekarang \\
& buka praktek lagi, ya. Kenapa tak omong-omong?" \\
& "Lho, bagaimana kau tahu?" (Doyle, 1992) \\
\hline Translators B & $\begin{array}{l}\text { "Seharusnya memang aku memikirkannya lebih dalam lagi. Sedikit hal kecil } \\
\text { lagi, Watson. Kuamati bahwa kau sudah berpraktik lagi. Kau tak } \\
\text { memberitahuku bahwa kau bermaksud masuk ke dalam sebuah kekang." } \\
\text { "Lalu, bagaimana kau bisa tahu?" (Doyle, 2014) }\end{array}$ \\
\hline
\end{tabular}

Seeing again Table 8 , it is found that the original author used the standard form of English language for the conversation between Mr. Holmes and Dr. Watson. In the source text, there are no instances of colloquialism, non-vernacular language, or particles that might signify informality. However, the translations of the excerpt by both translators are very distinctive. Translator A deliberately added interjection such as wah, kan, ya and tho in her translation. Meanwhile, Translators B closely followed the source text and translated it faithfully.

In Indonesian, the interjections which are mentioned above wah, kan, $y a$ and $l h o$ ) are commonly used to express ranges of emotive functions (Kusno, 1986, as cited in Widiatmoko \& Waslam, 2017). In Indonesian, these interjections could be considered as markers of colloquialism and are usually 
found and used in casual conversation, especially in the conversation between people who know each other very well. In the story, Mr. Holmes and Dr. Watson were close to each other even though Mr. Holmes and Dr. Watson had not met for a while since Dr. Watson got married. On several occasions, this can be seen from the way they fondly addressed each other as "my dear Holmes" or "my dear Watson." By displaying colloquialism in the conversation, Translator A might want to convey that Mr. Holmes and Dr. Watson had a close relationship, and they were comfortable with each other; thus, speaking casually and informally to each other is a normal occurrence. Translators B, on the other hand, decided to translate according to the source text. They translated the conversation in standardized English into a conversation in standardized Indonesian.

\section{E. Discussion and Further Implication}

As seen in the results, from the analysis of the lexical richness and average sentence length, it can be summarized that both translators exhibited an almost similar level of diversity in terms of vocabulary. However, compared to Translators B, Translator A preferred conciseness in rendering the source text into the target text. This is particularly evident from the way Translator A deliberately translated the source text as simple as possible despite the complexity of the source text. Meanwhile, Translators B preferred to stick as close as possible to the source text by replicating the complexity of the source text into the target text.

From the analysis of the overall text, the researcher would like to highlight that Translator A exhibits freer and more flexible approach whereas Translators $\mathrm{B}$ are more faithful in translating the story. Compared to Translators B, Translator A exerted greater effort to accommodate the target readers and to ensure the target readers' comprehension, convenience, and ease of reading. This is especially evident from the way Translator A dealt with elements that are problematic in the source text such as cultural terms, degree of formality, and so on. Meanwhile, Translators B preferred to stay faithful to the source text. Minimal focus and effort were given to accommodate the target readers which is evident from the lack of explanation on terms that were directly transferred from the source text.

Based on the observation of the findings, the general overview of the translators' style could be acquired. Translator A's style in translating is more oriented to target text and target readers whereas Translator $\mathrm{B}$ is more inclined to adhere to the style of the original author and the source text. 
Halim, S.W., Translator Style: An Analysis on Two Indonesian Translations of 213 "A Scandal in Bohemia"

Even though both translators translated the same source text, it is very clear that both translators have their own ways of translating the text and dealing with the issues.

On the theoretical level, what can be inferred from the observation on both translators' style in translating the story? This observation further cements that when translators translate literary texts, their individuality and creativity often bleed into their translation, and according to Boase-Beier (2006, cited in Wang \& Li, 2011), it is an unavoidable occurrence. It shows that the notion of translation invisibility might not be prevalent and valid in real translation practice and therefore, should not be considered the standard in determining the quality of translation. Of course, it is a job of the translators to be the bridge between the original author and the target readers who might not speak and understand the same codes and signals of communications. However, attempting to be a truly invisible bridge is an impossible undertaking as the previous studies and this research have illustrated and highlighted. No matter how good the translators are, there would always be some parts in which the translators have to compromise in order to deliver the original author's message and intention to the target readers, and that form of compromise might come out in distinctive ways across different translators as seen in this research.

On the practical level, it shows that literary translators should be granted more space and opportunities to be creative in translating literary work. Of course, the main purpose of translating is to convey the stories in the target language and to allow the target readers to access the mind of the original author. However, the freedom to be creative in translating the story and solving translation issues should be celebrated and encouraged more among literary translators. Furthermore, in the area of translator training, it is important to emphasize to the student translators that literary translation is different from scientific translation, and in literary translation, their individualistic style and creativity in translating the source text would be welcomed and appreciated. Thus, on a broader note, the teaching and evaluation methods for training translators in the area of literary translation should be adjusted as well in order to accommodate the aspect of creativity.

\section{CONCLUSION}

Translator's style is one of the subtle aspects of translation practice. From this research, it was found that both Indonesian translators of Doyle's 
"A Scandal in Bohemia" have their own distinctive styles in translating the story. Translator A was more target-reader-oriented whereas Translators B was more source-text-oriented. This can be seen from the analysis that the researcher conducted on several findings that were generated from both automatic and manual data collection procedures.

Despite the fact that this research is small-scale in nature, it further cements the notion that translators have their own styles in translating, and therefore, the quality of their work should not be judged on the basis of whether or not they are able to be invisible in their undertaking. Creativity is a part of their craft, and it appears in an individualistic manner. It also further emphasizes that translation is not merely the mirror of the original source text. It is a creative process that warrants further appreciation from the readers and thus, should not be treated as lesser activity compared to the writing activity.

This research focuses on the distinctive styles between the Indonesian translators of Doyle's "A Scandal in Bohemia". Of course, the difference of style might be influenced by other factors outside of the translators themselves, such as the translation brief, the instructions from the clients and publishers, the interference from the editors, and so on. However, since the researcher treated the final translation product as the reflection of the translators' style, those external factors were not analyzed. For further study, the researcher would suggest future researchers conduct closer investigations on those external factors in order to generate more comprehensive findings. Moreover, as Baker (2000) stated, it might be a good idea to focus on the translators' background as well in order to identify the motivation and the reasons why certain translators translate the ways they do.

\section{REFERENCES}

Baker, M. (2000). Towards a Methodology for Investigating the Style of a Literary Translator. Target. International Journal of Translation Studies, 12(2), 241-266.

https://doi.org/https://doi.org/10.1075/target.12.2.04bak

Boswell, J. (n.d.). Encyclopædia Britannica.

Crocker, R. A. (2009). An introduction to qualitative research. In Heigham \& R. A. Crocker (Eds.), Qualitative research in applied linguistics: A practical introduction (pp. 3-24). Palgrave Macmillan. 
Halim, S.W., Translator Style: An Analysis on Two Indonesian Translations of 215 "A Scandal in Bohemia"

Doyle, A. C. (1892). Scandal in Bohemia. In The Adventures of Sherlock Holmes (pp. 1-16). George Newnes.

Doyle, A. C. (1992). Skandal di Bohemia. In D. Dianasari (Ed.), Petualangan Sherlock Holmes (pp. 7-46). PT. Gramedia Pustaka Utama.

Doyle, A. C. (2014). Skandal di Bohemia. In A. Asnawi \& Sutrisno (Eds.), Sherlock Holmes: A Collector's Edition (pp. 3-25). Indoliterasi.

Giugliano, M. (2017). What the analysis of style in translation can say. Disentangling styles in Giovanni Giudici's translations of poetry. Lingue e Linguaggi, 21, 107-127.

https://doi.org/https://doi.org/10.1285/i22390359v21p107

Kusno, G. (2015). Singkatan bahasa Indonesia yang antik dan lucu. Kompasiana.

Li, D., Zhang, C., \& Liu, K. (2011). Translation style and ideology: A corpusassisted analysis of two english translations of hongloumeng. Literary and Linguistic Computing, 26(2), 153-166. https://doi.org/https://doi.org/10.1093/1lc/fqr001

Lynch, G., \& Vogel, C. (2018). The translator's visibility: Detecting translatorial fingerprints in contemporaneous parallel translations. Computer Speech and Language, 52, 79-104.

https://doi.org/https://doi.org/10.1016/j.csl.2018.05.002

Marco, J. (2004). Translating style and styles of translating: Henry James and Edgar Allan Poe in Catalan. Language and Literature, 13(1), 73-90. https://doi.org/https://doi.org/10.1177/0963947004039488

Mastropierro, L. (2018). Key clusters as indicators of translator style. Target. International Journal of Translation Studiesarget. International Journal of Translation Studies, 30(2), 240-259. https://doi.org/https://doi.org/10.1075/target.17040.mas

Masubelele, R. (2018). Do Literary Translators Have a Style of Their Own? Lessons from C.S.Z. Ntuli's Translation of D.B.Z. Ntuli's Short Story: Uthingo lwenkosazana (The Rainbow). Journal of Literary Studies, 13(1), $42-55$.

https://doi.org/https://doi.org/10.1080/02564718.2015.1084819

Née. (n.d.). Merriam-Webster Dictionary. 
216 Celt: A Journal of Culture, English Language Teaching \& Literature, Volume 20, Number 2, December 2020, pp. 195 - 216

Saldanha, G. (2011). Translator style: Methodological considerations. The Translator, 17(1), 25-50.

https://doi.org/https://doi.org/10.1080/13556509.2011.10799478

Scott, M. (2016). WordSmith Tools version 7. Lexical Analysis Software.

Venuti, L. (2008). The Translators' Invisibility: A History of Translation (2nd ed.). Routledge.

Wang, Q., \& Li, D. (2011). Looking for translator's fingerprints: A corpusbased study on Chinese translations of Ulysses. Literary and Linguistic Computing, 27(1), 81-93.

https://doi.org/https://doi.org/10.1093/llc/fqr039

Widiatmoko, B., \& Waslam. (2017). Interjeksi dalam Bahasa Indonesia: Analisis pragmatik. PUJANGGA Jurnal Bahasa Dan Sastra, 3(1), 83-97. 